\section{Tax Evasion in the Countries of the European Union - \\ Challenges for Professionals}

Silviu DUȚULESCU, Ph.D. Student, Bucharest University of Economic Studies, e-mail: silviudemetrius@yahoo.com

Univ. Prof. Ileana NIŞULESCUASFRAHZADEH, Ph. D., Bucharest University of Economic Studies, e-mail: ileana.nisulescu@yahoo.com

\section{Abstract}

Tax evasion is a very complex phenomenon, with wide social implications, but with a special manifestation in the economic sector, managing in some cases to seriously affect the standard of living of citizens.

The research of this phenomenon started from studies commissioned in 2015 by the European Parliament, which established the losses registered by each member country of the European Union as a result of the phenomenon of tax evasion. Based on this information, new elements have been added from the studies of other authors as well as from our own investigation and in this way the connection between the size of the tax evasion and the volume of the underground economy at the level of the European Union states has been demonstrated.

An important role in this demonstration was represented by the variable, the level of taxation, which showed that the fiscal pressure can to some extent influence the evasive behavior of the commercial entities that choose to increase their profit by techniques located outside the legal boundaries.

An improvement of evasion behavior can come from auditors who, through the recommendations they make to their clients, can make them aware of the danger posed by the tax evasion on the health of the national economy.

Keywords: tax evasion, underground economy, European Union, level of taxation

JEL Classification: C89, D11, 011

To cite this article:

Duțulescu, S., Nişulescu-Asfrahzadeh, I. (2019), Tax Evasion in the Countries of the European Union - Challenges for

Professionals, Audit Financiar, vol. XVII, no. 4(156)/2019, pp. 689-696, DOI: 10.20869/AUDITF/2019/156/028

To link this article:

http://dx.doi.org/10.20869/AUDITF/2019/156/028

Received: 16.08.2019

Revised: 22.08 .2019

Accepted: 10.10.2019 


\section{Introduction}

Currently, there is a high effervescence of the business environment, which is in a continuous expansion of activity in increasingly complex and innovative fields, for which the evolution of results is very difficult to anticipate.

For this fact responsible is also the technological development that influences our lives more and more, and with it also improve the techniques used by traders, in trying to pay taxes as low as possible. Some of them, especially the large companies, opt for tax advisory services to optimize costs, while small traders remain faithful to the techniques of misreporting real values to the authorities.

Some authors ${ }^{1}$ have even advanced classifications of this phenomenon in: legal tax evasion and illegal tax evasion. We consider that the association between the word evasion and legality is an unfortunate one, evasion assuming a violation of legality. Therefore, we opt for the use of "fiscal optimization" instead of the phrase "legal tax evasion".

The subject of tax evasion is important both for the authorities and for the whole society, being largely responsible for the insufficiency of the funds allocated to the services for the population (health care services, emergency response services and natural disasters, emergency services, guarding and protection services, providing free education up to a certain level, etc.).

The phenomenon of tax evasion is closely linked to the level of the underground economy. Although the underground economy comprises a wide spectrum of activities outside the law, some of them represent the basis for calculating the size of tax evasion. It is very important to study the evolution and behavior of the underground economy, as a rapid neutralization of it can create serious economic imbalances especially at the level of the poor categories, and here we mention the subsistence economy which ensures a minimum standard of living for people in rural areas, who do not have other sources of income.

There are authors such as Voicu (2012), who consider that a low level of the underground economy, referring to the activities of craftsmen, can be a positive factor for

$1 \mathrm{http}: / /$ revistaprolege.ro/diferente-evaziunea-fiscala-legalatax-avoidance-frauda-fiscala-tax-evasion-incriminata-cainfractiune/ the economic development of the respective society, and the negative effects that would result from these activities of craftsmen are almost unnoticed compared to the benefits they bring to the community.

The acceptance by the authorities of these types of crafts activities is a beneficial action, since indirectly such activities encourage work, even if we speak of a form of work not fully reported to the authorities. Otherwise, the craftsmen remain without any form of income and it is very possible that a good part of them will become socially assisted and in this way the authorities will be the ones who will support them materially.

\section{References from the snecialised literature in the field of fiscal evasion}

Tax evasion, as part of the underground economy, included in the large mass of activities that make up the economic crime, was born with the appearance of trade, in order to avoid paying part of the profit to the authorities.

This desire persists even today, the difference being that with the evolution of the human society, the techniques applied by the traders regarding the payment of as few contributions as possible to the state budget have evolved. Ciupitu and Tudorache (2015) classify this phenomenon into: identified tax evasion and unidentified tax evasion. They consider that the first type is connected to the official economy, which the authorities are aware of, while the unidentified tax evasion stems from the activities that make up the underground economy, which the authorities are not aware of and which make no direct contribution. In the same direction, Achim (2017) considers that tax evasion is directly connected to the underground economy, and this is also the main element of difficulty in quantifying the size of tax evasion, since the real size of the underground economy is unknown to the authorities.

According to Dinga (2008), tax evasion is not a specific component of the underground economy as it involves legal activities not reported to the authorities and, in this context, it would be more appropriate for the tax evasion to be located in the border area between the underground economy and the official economy. We consider that tax evasion is part of the underground 
economy, as this economy comprises all legal and illegal activities, and tax evasion only covers undeclared legal activities.

Voicu (2012) defines the underground economy as the totality of activities that may be commercial or otherwise, legal or illegal and which may be dangerous or nondangerous for society. There are authors who have turned their attention to analyzing the underground economy and even made measurements of it. Among them we mention: Alm, Martinez-Vasquez and Schneider (2004), respectively Schneider and Klingmair (2004).

We believe that between the underground economy and tax evasion there is an interdependence link, and a set of legislative measures directed against the activities that compose the underground economy will certainly be felt through a significant reduction of the tax evasion phenomenon.

Olabisi (2010) perceives tax evasion as an intentional practice of the economic agents not to report the real values to the authorities, in order to be able to reduce the fiscal obligation as much as possible, even if this technique involves fraudulent actions.

We consider that tax evasion is much more complex, as it can be extended in the sense that economic agents can resort not only to the truncated reporting of tax information, but even to distorting them in their favor, so that, according to fictitious transactions, it asks for money from the state, such as illegal VAT refunds.

\section{Research methodology}

The current research has been carried out in an area where there are not many recent studies and both the academic environment and the authorities show their real interest in the elaboration of national policies regarding the reduction of economic crime and combating the phenomenon of tax evasion.

The research started from the study "The European Tax Gap, A report for the Socialists and Democrats Group in the European Parliament", ordered by the European Parliament. It established for the year 2015, the amount of losses due to the phenomenon of tax evasion and incurred by each member state of the European Union. Taking advantage of these data, we consulted Euro stat statistics, from where we collected information on the value of GDP for each of the 28 Member States and based on these elements, we were able to determine the weight of tax evasion in the GDP of each country. This was achieved by performing a proportion according to the formula:

\section{(Total loss generated as a result of tax evasion / $\left.G D P_{i}\right) * 100$,}

where $\mathrm{i}=$ the analyzed country.

The acquired elements were corroborated with another study, Medina and Schneider (2018), which measures the share of the underground economy related to GDP, for 159 countries, including EU states.

Based on this information, it was possible to determine the weight of tax evasion from the total underground economy, the difference being the other forms of economic crime, such as: corruption, human trafficking, prostitution, drug trafficking, crime against the environment, kidnappings in the prospect of obtaining redemptions, etc.

The working hypothesis from which we start is that the volume of underground economy represents the basis of calculation for tax evasion. In this sense we have the percentage $X$ (which represents the share of the underground economy in GDP, according to the Medina and Schneider study, 2018), from which we subtract the percentage $Y$ (which represents the weight of the tax evasion in the GDP, calculated by us according to the calculation formula presented above). The result of this difference (X-Y) is the share of the other forms of economic crime, other than the tax evasion reported to the GDP.

There were other proportions made between the volume of tax evasion compared to the volume of the underground economy, the calculation formula being the same as the one presented above, the only difference being the variables used. So, the weight of tax evasion in the underground economy was calculated using the formula:

\section{(Tax evasion / Underground economy) * 100.}

To these was added a variable, the level of taxation, which was taken from the reports of the World Bank, in order to establish various connections and correlations between the size of tax evasion and the level of taxation. This variable reflects the weight of 
all the taxes that an economic entity owes to the authorities, referring to its own profit.

Starting from these variables, a series of correlations were made both between the weights of tax evasion and the size of the underground economy as a percentage of GDP, and between the weight of tax evasion in relation to the other forms of economic crime. The aim was to identify the different features that the analyzed states might exhibit, features that could not have been anticipated in the absence of such a study.

\section{Results and discussions}

Based on the analysis of the collected data, the countries with the highest values of tax evasion are Greece and Italy (over 11 percent of GDP), while our country has a tax evasion of $10.11 \%$ compared to the GDP of 2015 . Italy has the largest tax evasion in the whole European Union, its value amounting to 190.9 billion Euros, while Greece and Romania have values below 20 billion Euros each as a result of the tax evasion phenomenon.

For a better understanding of the pillars that support this scientific endeavor, the entire database has been condensed as Table no. 1.

\begin{tabular}{|l|c|c|c|c|c|}
\hline \multicolumn{6}{|c|}{ Table no. 1. Database with centralization of the main variables under analysis } \\
\hline $\begin{array}{c}\text { Country } \\
\text { Share of tax } \\
\text { evasion with } \\
\text { respect to GDP (\%) }\end{array}$ & $\begin{array}{c}\text { Share of underground } \\
\text { economy relative to } \\
\text { GDP (\%) }\end{array}$ & $\begin{array}{c}\text { Average level } \\
\text { of taxation (\%) }\end{array}$ & $\begin{array}{c}\text { The share of tax } \\
\text { evasion in the } \\
\text { underground } \\
\text { economy }\end{array}$ & $\begin{array}{c}\text { The share of } \\
\text { economic crime in } \\
\text { the underground } \\
\text { economy }\end{array}$ \\
\hline England & 3.35 & 8.32 & 33.70 & 40.26 & 59.74 \\
\hline Austria & 3.75 & 9.01 & 52.00 & 41.62 & 58.38 \\
\hline Belgium & 7.39 & 17.80 & 57.80 & 41.52 & 58.48 \\
\hline Bulgaria & 8.39 & 20.83 & 27.00 & 40.28 & 59.72 \\
\hline Czech Republic & 5.22 & 10.47 & 48.50 & 49.86 & 50.14 \\
\hline Cyprus & 9.02 & 32.20 & 23.20 & 28.01 & 71.99 \\
\hline Croatia & 7.85 & 22.96 & 18.80 & 34.19 & 65.81 \\
\hline Denmark & 6.41 & 14.70 & 26.00 & 43.61 & 56.39 \\
\hline Estonia & 6.78 & 18.49 & 49.30 & 36.67 & 63.33 \\
\hline Finland & 5.10 & 13.30 & 40.00 & 38.35 & 61.65 \\
\hline France & 5.36 & 11.65 & 66.60 & 46.01 & 53.99 \\
\hline Germany & 4.10 & 7.75 & 48.80 & 52.90 & 47.10 \\
\hline Greece & 11.23 & 26.45 & 49.90 & 42.46 & 57.54 \\
\hline Ireland & 2.63 & 9.58 & 25.90 & 27.45 & 72.55 \\
\hline Italy & 11.56 & 22.97 & 65.40 & 50.33 & 49.67 \\
\hline Latvia & 6.99 & 16.62 & 35.00 & 42.06 & 57.94 \\
\hline Lithuania & 8.28 & 18.65 & 42.60 & 44.40 & 55.60 \\
\hline Luxemburg & 3.10 & 10.38 & 20.20 & 29.87 & 70.13 \\
\hline Malta & 9.33 & 29.43 & 41.60 & 31.70 & 68.30 \\
\hline Netherlands & 3.22 & 7.83 & 39.00 & 41.12 & 58.88 \\
\hline Poland & 8.04 & 16.67 & 38.70 & 48.23 & 51.77 \\
\hline Portugal & 6.12 & 17.82 & 42.40 & 34.34 & 65.66 \\
\hline Romania & 10.11 & 22.94 & 43.20 & 44.07 & 55.93 \\
\hline Slovakia & 6.82 & 11.18 & 48.60 & 61.00 & 39.00 \\
\hline Slovenia & 6.69 & 20.21 & 32.00 & 33.10 & 66.90 \\
\hline Spain & 5.55 & 22.01 & 58.20 & 25.22 & 74.78 \\
\hline Sweden & 3.76 & 11.74 & 49.40 & 32.03 & 67.97 \\
\hline Hungary & 8.21 & 20.49 & 48.00 & 40.07 & 59.93 \\
\hline Sourc: & & & & \\
\hline
\end{tabular}

Source: Author's processing, 2019 
Based on the analysis of the collected values, we consider that between the size of the volume of the underground economy and the tax evasion there is a quite close correlation. With the exception of Cyprus and Malta, the 3 countries mentioned above also reach the highest values of the share of the underground economy in GDP.

Another variable largely responsible for the volatility of the evolution of tax evasion is the level of taxation. All 3 countries (Italy, Greece and Romania) have an average level of taxation above the average of the European Union countries $(41.85 \%)$.

Among the countries with the lowest level of tax evasion we identify Ireland (2.63\%), Luxembourg $(3.10 \%)$ and the Netherlands (3.22\%), the level of taxation being below the European Union level. By comparison, the Netherlands, although it has a GDP of over 3.5 times that of Greece, the losses generated by tax evasion are almost identical $(€ 22.2$ billion in the Netherlands and $€$ 19.9 billion in Greece, respectively).

According to the reasoning stated in the methodology, if from the weight of the underground economy we will remove the component represented by the tax evasion we will obtain the weight of the economic crime. From the point of view of mathematics, we can associate the level of taxation with the set of natural numbers $\mathrm{N}$, and the phenomenon of economic crime with the set of real numbers $\mathrm{R}$.

Ireland due to a very low share of tax evasion has one of the highest shares of economic crime, amounting to $72.55 \%$ of the volume of the underground economy, below $10 \%$ of GDP. Spain ranks in the first position in a ranking of the countries with the largest losses as a result of economic crime, except for tax evasion.

Although it has a very low level of tax evasion, only 5.5\% of GDP, it has one of the highest percentages of the underground economy of over $20 \%$ of GDP and a share of economic crime compared to the volume of the underground economy of over $74 \%$.

Contrary to expectations, Spain and France, although they have among the highest levels of taxation in the whole European Union, manage to maintain a very low level of tax evasion around $5 \%$ of GDP, which reflects an increased efficiency in implementing fiscal policies.

In Figure no. 1 we have illustrated for each member state of the European Union, economic underground decomposition into the constituent elements: tax evasion, corruption, drug trafficking, prostitution, kidnappings, trade in radioactive materials, etc.

\section{Figure no. 1. Distribution of the underground economy by main components}

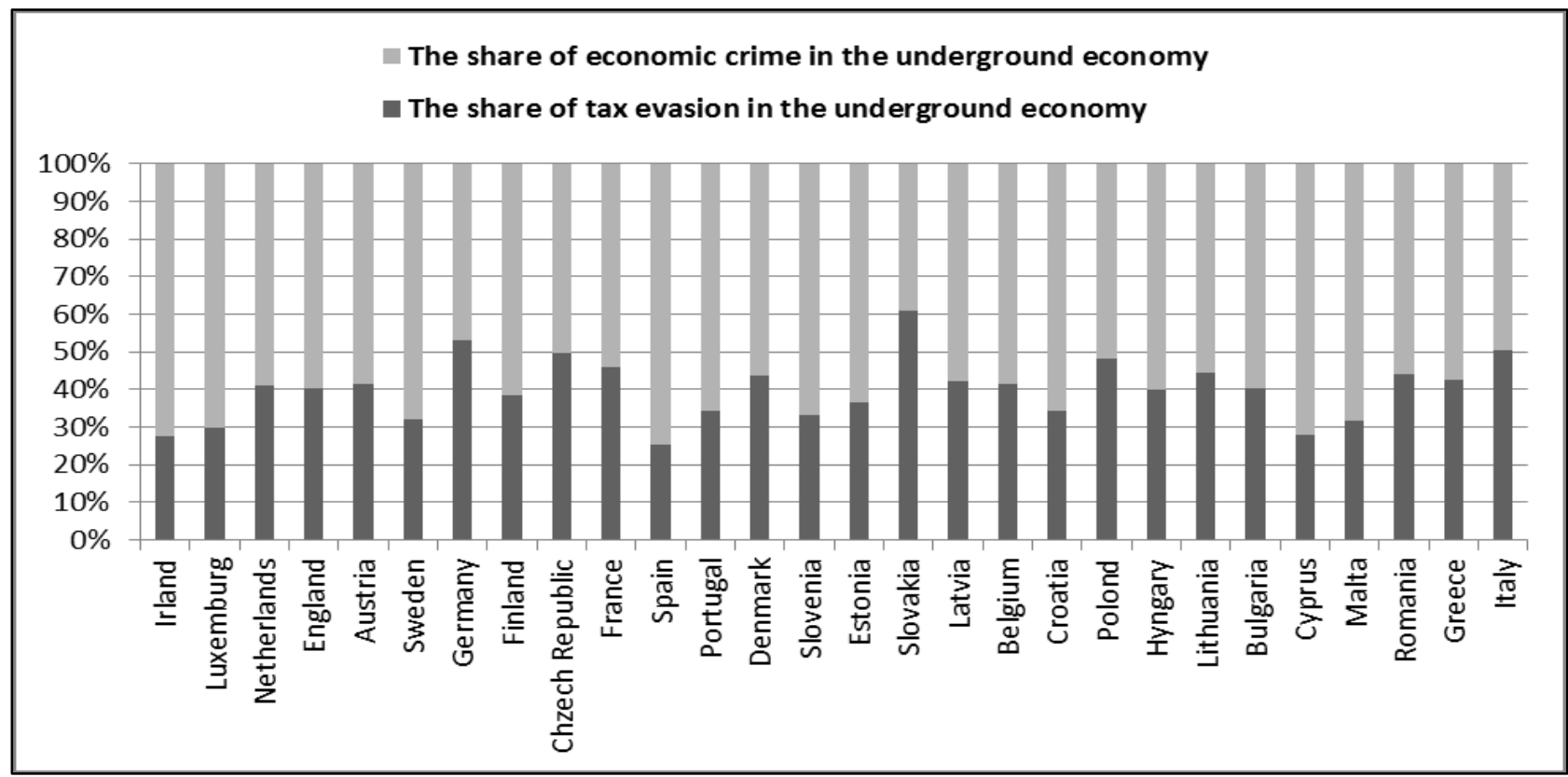

Source: Author's processing, 2019

No. 4(156)/2019 
According to the chart from Figure no. 1, in 25 countries the share of economic crime is higher than that of tax evasion in the underground economy. There are clearly 3 countries, Ireland, Spain and Cyprus, which show very sharp variations, the share of economic crime amounting to over $70 \%$ of the volume of the underground economy.

On closer examination, we identify countries, such as Germany, Italy and Slovenia that reach higher weights for the phenomenon of tax evasion compared to other forms of economic crime.

If Germany and Italy have a significantly higher level of taxation than the European Union average, the share of the underground economy in GDP cannot be a plausible argument since Germany is the country with the lowest level of underground economy among all the countries analyzed.

Turning our attention to Romania, according to the annual report prepared by the Fiscal Council ${ }^{1}$, our country manifested in 2006-2015 a pro-cyclical policy, which counter-productively stimulated the national economy during the period of economic expansion (2006-2008), and in the period 2010-2015, when the Romanian economy evolved at a low level, with negative annual economic developments, these fiscal policies acted as a brake, thus amplifying the economic fluctuations that were negative in most of the states of the world anyway.

According to the same report, the level of tax collection decreased significantly in 2016 compared to 2015, and as a result of the changes made by the new Fiscal Code, the share of tax revenues in GDP decreased substantially, this being the second lowest of all the states in the European Union. As an order of magnitude, at the level of 2016 the level of tax revenues reported to GDP occupied a weight of 25.9 percent, being the penultimate place in the European Union and at a distance of 13.9 percentage points compared to the average level recorded by the Member States.

The structure of the tax revenues in Romania, saw a change in the level of 2016 compared to 2015 due to the reduction of VAT rates, which even after this reduction presupposes a substantial weight in the total of indirect taxes, which stands at $43.6 \%$ from the total of tax revenues, compared to the European Union average, which is $33.7 \%$.

\footnotetext{
1 http://www.consiliulfiscal.ro/RA2016roiunie2017.pdf
}

A progress made by our country consists in improving the situation regarding the management of arrears by the state authorities, which has favorably boosted the economic environment. Even the situation of overdue payments involving a period of less than 90 days and which according to the law no 500/2002 does not fall into the category of arrears, has improved substantially, at the end of 2016 their total value was over 21 percent lower compared with the year 2015.

We believe that this financial discipline that was started by the authorities must be continued, and the auditor profession can play an important role in this challenge.

We consider that a correct position of the authorities regarding the fulfilment of the financial obligations could represent a powerful signal for the economic environment to do the same with the tax authorities by honoring the due taxes. In this way we will witness a gradual reduction in the level of tax evasion, and the auditors through the services they provide to the economic agents, can influence them to avoid committing the tax evasion acts.

Even if there are inconsistencies, or gaps, in the tax legislation, auditors can use professional judgment in good faith and even make recommendations to economic agents regarding the approach of a species for which the legislative framework is not well consolidated.

We consider that studying the evolution over time of social phenomena that have a strong connection with the economic sphere is very vital for both authorities and the whole society, since the standard of living of people can be visibly influenced by the way these phenomena manifest themselves.

In this regard, we intend that in a future study, we should analyze the evolution of these phenomena for a period of 10 years, and then based on the information we will obtain to try to make a prediction of their evolution.

\section{Ronclusions}

Tax evasion is closely linked to the underground economy for most of the European Union states, and the action of the authorities to reduce the underground economy will also be reflected by a decrease in tax evasion.

We appreciate that the level of taxation has a noticeable influence on the size of tax evasion, but we emphasize 
that there are countries with a somewhat atypical behavior, in the sense that although they have high levels of taxation, well above the average of the EU countries, they manage to maintain their level of tax evasion around $5 \%$ (France and Spain).

As demonstrated during the study, tax evasion is modelled to some extent by the level of taxation, the first 3 countries with the highest values of tax evasion having levels of taxation above the average of EU states; while in countries with the lowest levels of tax evasion (Ireland, Luxembourg and the Netherlands), the level of taxation was below the EU level.

The largest loss recorded by a country from tax evasion is Italy, which stands at $11.56 \%$ of GDP, and in absolute value, the loss exceeds 190 billion Euros annually.

Spain, the fifth economic power among the countries of the European Union, has the highest level of economic crime; the value of the annual losses recorded from tax evasion, amounts to approximately 60 billion Euros, respectively $5.55 \%$ of GDP.

Following the analyzes, it has been found that for most European Union states, the size of the underground economy is shaped by socio-economic phenomena, other than tax evasion

We consider that the authorities through the strategies they devise for increasing the standard of living of the population should take into account, not only the fiscal area that can be treated relatively easily by mathematical algorithms, but also the social behaviors that have a strong economic impact on the economy of a state.
Among the forms of economic crime, which make a substantial contribution to what we call the underground economy, we mention: the phenomenon of corruption, which is now widespread in various forms in all the states of the world, or of criminal activities such as drug trafficking, prostitution (in the states where it is not legalized), kidnappings, etc.

Although the phenomenon of tax evasion in the most common form, implies the concealment of some information or their incomplete presentation to the authorities, so as the economic entities could pay taxes as low as possible, there is another form of manifestation of the phenomenon of tax evasion, which supposes that on the basis of fictitious transactions, the economic entities request money from the state.

At the national level, the Romanian authorities have succeeded in tempering the situation of the tax evasion phenomenon through their own financial discipline, which implies a significant decrease of the time periods with the payment of arrears as well as of the other duties that are not considered arrears (period less than 90 days) and which, in 2016, registered a decrease by $21.3 \%$ compared to the previous year.

An important role is also played by the auditor profession, which can act through the nature of its activity and recommendations of good faith, quite effective on the mindset of the economic agents in the sense of discouraging them to resort to evasion practices.

\section{REFERENCES}

1. Achim, M. (2017), Corupția şi economia subterană. Teorii şi studii, Presa Universitară Clujeană, ISBN 978-606-37-0217-4, pp. 17-64.

2. Alm, J., Martinez-Vazquez, J. şi Schneider, F. (2004), Sizing the Problem of the Hard-to-Tax, Contributions to Economic Analisys, Elsevier, no. 268, pp 11-75.

3. Ciupitu, S.A. şi Tudorache, D. (2015), Fiscal pressure causes major problems to Romanian economy: underground economy and corruption; Dimitrie Cantemir Christian University, Knowledge Horizons - Economics, no. 7(1), pp. 128-130.

4. Dinga, E. (2008), Considerații teoretice privind evaziunea şi frauda fiscală, Studii financiare, no. 4/2008, pp. 20-50.
5. Olabisi, J. (2010), An assessment of tax evasion and tax avoidance in Lagos, Nigeria, Journal of research in national development, no. 8(1), pp. 17-27.

6. Schneider, F. şi Klinglmair, R. (2004), Shadow economies around the world: What do we know? Universitat Linz, Working paper, no. 403.

7. Voicu, C. (2012), Ştiința economică şi teoria economiei „subterane”, Economie teoretică şi aplicată, vol. 19, no. 7(572), pp. 52-66.

8. Tax evasion classification, available online at: $<$ http://revistaproleqe.ro/diferente-evaziuneafiscala-leqala-tax-avoidance-frauda-fiscala-taxevasion-incriminata-ca-infractiune/> [Accessed July 20, 2019]. 
9. The share of the underground economy, relative to the GDP of each country, available online at:<https://www.theglobaleconomy. com/rankings/shadow_economy/> [Accessed July 13, 2019].

10. World Bank reports on the level of taxation for the countries of the world in 2015, [online] available at: <https://www.doingbusiness.org/ content/dam/doingBusiness/media/AnnualReports/English/DB15-Full-Report.pdf> [Accessed July 17, 2019].

11. Study, The European Tax Gap, A report for the Socialists and Democrats Group in the European Parliament, [online] available at:

$<h t t p s: / / w w w . s o c i a l i s t s a n d d e m o c r a t s . e u / s i t e s / d e f a$ ultffiles/2019-01/the_european_tax_gap en_190123.pdf> [Accessed July 11, 2019].

12. The value of GDP at the level of 2015 for each country in the European Union, [online] available at:

$<h t t p: / / a p p s s o . e u r o s t a t . e c . e u r o p a . e u / n u i / s h o w$. do?dataset=nama_10_gdp\&lang=en> [Accessed July 10, 2019].

13. Annual report prepared by the Fiscal Council of Romania, available online at: <http://www.consiliulfiscal.ro/RA2016roiunie2017.p df > [Accessed August 13, 2019]. 